\title{
Importance of viruses and Legionella pneumophila in respiratory exacerbations of young adults with cystic fibrosis
}

\author{
J EFTHIMIOU, MARGARET E HODSON, P TAYLOR, AG TAYLOR, JC BATTEN \\ From the Brompton Hospital and Cardiothoracic Institute and the Central Public Health Laboratory, London
}

ABSTRACT From January to April 198046 young adults with cystic fibrosis were studied for $\overrightarrow{\mathcal{O}}$ evidence of infection with a wide variety of microorganisms, including viruses and Legionella 은 pneumophila. Two groups of patients were investigated: a "deteriorated" group of 24 patients who had experienced an increase in lower respiratory tract symptoms and fall in lung function $T$ values in the course of one month before the start of the study and a "stable" group of 22 patients with no such deterioration. All serological tests were repeated at one month and then one year after the beginning of the study. A fourfold rise in titres of antibodies to various viruses, $\mathrm{Myco}$ plasma pneumoniae, and Coxiella burnetii was obtained in seven (29\%) of the deteriorated group but in only one $(4.5 \%)$ of the stable group $(p<0.05)$. One other patient showed a fourfold rise in $L$ pneumophila antibody titre (on the basis of the indirect fluorescent antibody test), which was accompanied by a respiratory illness consistent with legionnaires' disease. Eight of the 46 patients $(17 \cdot 4 \%)$ had demonstrable titres of antibody against $L$ pneumophila (1/32 or above).

Bacteria, notably Pseudomonas aeruginosa, are assumed to be the most important cause of respiratory exacerbations in patients with cystic fibrosis. ${ }^{2}$ The incidence of viral and mycoplasma infections has not been convincingly shown to be higher in patients with cystic fibrosis than in healthy controls, ${ }^{34}$ but the consequences of these infections may be more serious. ${ }^{4-6}$ Consequently, it is generally recommeded that patients with cystic fibrosis should be immunised against influenza. ${ }^{67}$ Despite extensive investigation, however, some $20 \%$ of the respiratory exacerbations in these patients may not be associated with any of the common bacteria or viruses. ${ }^{8}$ Legionella pneumophila, which has a predilection for patients who are debilitated ${ }^{9}$ or suffer from chronic lung disease,,$^{10}$ is a plausible cause of respiratory deterioration in patients with cystic fibrosis. Apart from a preliminary report from Philadelphia in which a stable population of patients with cystic fibrosis was screened for antibodies against $L$ pneumophila as a single epidemiological observation," almost nothing is known of the role of

Address for reprint requests: Dr J Efthimiou, Department of Thoracic Medicine, University College Hospital, London WC1E 6AU.

Accepted 1 November 1983 this bacterium in cystic fibrosis. The present study was undertaken to investigate the role of viruses and $L$ pneumophila in the acute respiratory exacerbations of young adults with cystic fibrosis.

\section{Patients and methods}

Forty six patients with cystic fibrosis ( 25 male, 21 female) with a mean age of $22 \cdot 2$ years (range 16-41 years) were studied for evidence of infection with viruses, L pneumophila, Mycoplasma pneumoniae, Coxiella burnetii, and Chlamydia psittaci, as well as for the usual bacterial pathogens. Both culture and serological methods were used.

The patients were the first 46 seen in the cystic $N$ fibrosis clinic at the Brompton Hospital from Janu- N ary to April 1980. All patients had had a uniform $\stackrel{\sim}{N}$ pattern of attendance at the clinic (monthly or more $\omega$ frequent) before the initial study visit. The patients were classified as either "deteriorated" or "stable." The deteriorated group consisted of 24 patients in $\stackrel{\Phi}{\mathscr{Q}}$ whom an increase in cough, sputum production or ? breathlessness was accompanied by an FEV, at least $15 \%$ less than the value obtained at a preliminary visit one month before. The stable group consisted of 22 patients who were both clinically stable and had steady lung function values. A control group of 
30 healthy hospital volunteers was also studied. Each group had similar numbers of men and women and similar age distributions. In all patients the diagnosis of cystic fibrosis had been established clinically and confirmed by the finding of a raised sweat sodium concentration (over $70 \mathrm{mmol}(\mathrm{mEq}) / \mathrm{l}$.

Nose and throat swabs and samples of sputum and serum were collected from the patients and controls at the initial visit. Antibodies against influenza A and $B$ and parainfluenza (serotype 1) viruses, adenovirus, respiratory syncytial virus, varicellazoster virus, $M$ pneumoniae, Chlamydia psittaci, and Coxiella burnetii were detected by complement fixation. An indirect fluorescent antibody test, using formolised yolk sac antigens, ${ }^{12}$ was used to detect antibodies to $L$ pneumophila serogroups 1-6. All serological tests were repeated one month and again one year after the patient's initial visit.

Three cell lines (primary monkey kidney, Hep-2 cells, human embryonic lung fibroblasts) were used for isolation of the previously mentioned viruses and rhinovirus. The relationship between the presence of demonstrable titres of antibody against $L$ pneumophila and the use of aerosol treatment, the number of hospital admissions in the preceding year, and the patient's lung function was examined. Lung function had been assessed at a preliminary routine outpatient visit one month before the start of the study and the tests were repeated subsequently at the initial visit when the patients were allocated to the "stable" or "deteriorated" groups.

The binomial, median, and $\chi^{2}$ tests and Fisher's exact test were used for statistical analysis.

\section{Results}

A fourfold rise in complement fixing antibody titre was observed in paired sera from seven $(29.2 \%)$ of the 24 patients in the "deteriorated" group and from one $(4.5 \%)$ of the 22 patients in the "stable" group, but in none of the healthy control group. Sequential antibody titres, from the time of the initial visit to the end of the study one year later, for the patients with positive results are shown in table 1. The agents responsible for these positive serological results were respiratory syncytial virus in two patients, influenza A virus, adenovirus (serotype 7), varicella-zoster virus, $M$ pneumoniae, and $C$ burnetii in the deteriorated group and an adenovirus (serotype 7) in the stable group. The patient with serological evidence of varicella-zoster infection had a rash and illness consistent with chickenpox. Only the two adenovirus and the varicella-zoster infections were confirmed by isolation of the virus in the three cell lines used. This low isolation rate probably reflects the low level of infection in the community at the time of the study. All of the infections in the deteriorated group were accompanied by acute exacerbations of lower respiratory tract disease.

The result of the indirect fluorescent antibody test for $L$ pneumophila are shown in tables 2 and 3 . One patient, in the deteriorated group (case 9), had a fourfold rise in antibody titre against $L$ pneumophila (serogroup 1) from $<1 / 16$ to $1 / 64$. This was accompanied by clinical deterioration responsive to treatment with erythromycin. In two other patients with $L$ pneumophila antibody titres of $1 / 32$ in February 1980 (cases 10 and 11) considerably raised titres of $1 / 128$ had been present in a pilot study carried out one year before the present study. In all, a total of eight patients $(17.4 \%)$ had demonstrable titres of antibody against $L$ pneumophila of $1 / 32$ or more in one or both of the original paired sera (seven in the deteriorated group and one in the stable group). Six were male and two female and all had Pseudomonas aeruginosa in the sputum. All had moderate to severe disease with airflow limitation but only one patient was receiving corticosteroid treatment. None of the healthy control group had antibody titres of more than 1/15. At follow up one year later the antibody titres in these eight patients had fallen to $1 / 16$ or less. All L pneumophila serogroups, except serogroups 3 and 5 , were represented in the positive results. Two of the patients with $L$ pneumophila antibody titres of $1 / 32$ (both to serogroup 4) also had raised antibody titres to a virus, respiratory syncytial virus in one patient and influenza $A$ virus in the other.

Significantly fewer patients in the stable group had serological evidence of non-bacterial infection $(p<0.05)$ but there was no significant difference between the stable and deteriorated groups in terms of their principal sputum pathogens-namely $P$ aeruginosa, Haemophilus infuenzae, and Staphylococcus pyogenes (table 4). Furthermore, the patients with serological evidence of infection with $M$ pneumoniae and Coxiella burnetii and those with $L$ pneumophila antibody titres of $1 / 32$ or more were similar to the rest of the patients in terms of the principal bacterial pathogens in their sputum. No significant association was found between demonstrable titres of antibody against $L$ pneumophila and the use of aerosol treatment, the number of hospital admissions in the preceding year, or FEV 1 and FVC.

Analysis of the data on the stable and deteriorated groups showed no significant differences in sputum bacteria or respiratory symptoms before the beginning of the study. The mean number of hospital admissions was 1.6 in the deteriorated group in the year preceding the study compared with 0.6 in the stable group $(\mathrm{p}<0 \cdot 05)$. The mean $(\mathrm{SEM}) \mathrm{FEV}_{1}$ was $1.32(0 \cdot 17) 1$ in the deteriorated group com- 
Table 1 Sequential complement fixing antibody titres in cystic fibrosis patients with positive serological results

\begin{tabular}{|c|c|c|c|c|c|c|}
\hline \multirow{2}{*}{$\begin{array}{l}\text { Patient } \\
\text { No }\end{array}$} & \multirow[t]{2}{*}{ Group } & \multirow[t]{2}{*}{ Organism } & \multirow{2}{*}{$\begin{array}{l}\text { Initial } \\
\text { visit }\end{array}$} & \multicolumn{3}{|l|}{ Antibody titre } \\
\hline & & & & At initial visit & $1 \mathrm{~m}$ later & $1 y$ later \\
\hline $\begin{array}{l}1 \\
2 \\
3 \\
4 \\
5 \\
6 \\
7 \\
8\end{array}$ & $\begin{array}{l}\text { Deteriorated } \\
\text { Deteriorated } \\
\text { Deteriorated } \\
\text { Deteriorated } \\
\text { Stable } \\
\text { Deteriorated } \\
\text { Deteriorated } \\
\text { Deteriorated }\end{array}$ & $\begin{array}{l}\text { Respiratory syncytial virus } \\
\text { Influenza A virus } \\
\text { Respiratory syncytial virus } \\
\text { Adenovirus } \\
\text { Adenovirus } \\
\text { Coxiella burnetii } \\
\text { Varicella-zoster virus } \\
\text { Mycoplasma pneumoniae }\end{array}$ & $\begin{array}{l}\text { Jan } 1980 \\
\text { Jan } 1980 \\
\text { Feb } 1980 \\
\text { Feb } 1980 \\
\text { Feb } 1980 \\
\text { Mar } 1980 \\
\text { Apr } 1980 \\
\text { Apr } 1980\end{array}$ & $\begin{array}{r}<1 / 20 \\
<1 / 20 \\
<1 / 20 \\
<1 / 20 \\
<1 / 20 \\
11 / 40 \\
<1 / 20 \\
<1 / 20\end{array}$ & $\begin{array}{l}1 / 320 \\
1 / 160 \\
1 / 160 \\
1 / 160 \\
1 / 160 \\
1 / 640 \\
1 / 160 \\
1 / 160\end{array}$ & $\begin{array}{r}<1 / 20 \\
<1 / 20 \\
<1 / 20 \\
<1 / 20 \\
<1 / 20 \\
1 / 40 \\
<1 / 20 \\
<1 / 20\end{array}$ \\
\hline
\end{tabular}

Table 2 Sequential Legionella pneumophila antibody titres in patients with cystic fibrosis having titres of 1/32 or more $\omega_{0}^{\omega}$ (indirect fuorescent antibody test)

\begin{tabular}{|c|c|c|c|c|c|}
\hline \multirow{2}{*}{$\begin{array}{l}\text { Patient } \\
\text { No }\end{array}$} & \multirow[t]{2}{*}{ Group } & \multirow[t]{2}{*}{ L pneumophila serogroup } & \multicolumn{3}{|l|}{ Antibody titre } \\
\hline & & & At initial visit & $1 \mathrm{~m}$ later & 1 y later \\
\hline $\begin{array}{r}2 \\
3 \\
9 \\
10 \\
11 \\
12 \\
13 \\
14\end{array}$ & $\begin{array}{l}\text { Deteriorated } \\
\text { Deteriorated } \\
\text { Deteriorated } \\
\text { Deteriorated } \\
\text { Deteriorated } \\
\text { Deteriorated } \\
\text { Deteriorated } \\
\text { Stable }\end{array}$ & $\begin{array}{l}4 \\
1 \\
1 \\
1 \\
2 \\
2 \\
1 \\
6 \\
6\end{array}$ & $\begin{array}{r}1 / 32 \\
1 / 32 \\
<1 / 16 \\
1 / 32 \\
1 / 32 \\
1 / 16 \\
1 / 32 \\
1 / 32\end{array}$ & $\begin{array}{l}1 / 32 \\
1 / 32 \\
1 / 64 \\
1 / 32 \\
1 / 32 \\
1 / 32 \\
1 / 32 \\
1 / 32\end{array}$ & $\begin{array}{r}<1 / 16 \\
1 / 16 \\
1 / 16 \\
1 / 16 \\
1 / 16 \\
<1 / 16 \\
1 / 16 \\
<1 / 16\end{array}$ \\
\hline
\end{tabular}

pared with $1.69(0.14) \mathrm{l}$ in the stable group ( $p<0.01)$; the FVC was $2.16(0.23) 1$ in the deteriorated group compared with $2.73(0.20) 1$ in the stable group $(\mathrm{p}<0.01)$.

\section{Discussion}

Serological evidence of viral, mycoplasma, and coxiella ("non-bacterial") infections was obtained in $29 \%$ of patients with acute exacerbations of their respiratory disease. The proportions have ranged from $20 \%$ to $39 \%$ in previous studes, ${ }^{4813}$ although in none of these was a "stable" group of patients also examined or tests for rhinoviruses, known to be important causes of respiratory illness, carried out. Significantly fewer patients in our stable group had serological evidence of non-bacterial infection, sug-

Table 3 Results of sequential Legionella pneumophila antibody tests in patients with cystic fibrosis who did not have antibody demonstrable at $\geqslant 1 / 32$ (indirect fuorescent antibody test)

\begin{tabular}{|c|c|c|c|c|}
\hline \multicolumn{3}{|l|}{ Antibody titre } & \multirow{2}{*}{$\begin{array}{l}\text { No of } \\
\text { deteriorated } \\
\text { patients }\end{array}$} & \multirow{2}{*}{$\begin{array}{l}\text { No of } \\
\text { stable } \\
\text { patients }\end{array}$} \\
\hline At initial visit & $1 \mathrm{~m}$ later & 1 y later & & \\
\hline $\begin{array}{r}<1 / 16 \\
1 / 16 \\
1 / 16 \\
1 / 16 \\
<1 / 16\end{array}$ & $\begin{array}{r}<1 / 16 \\
<1 / 16 \\
1 / 16 \\
1 / 16 \\
<1 / 16\end{array}$ & $\begin{array}{r}<1 / 16 \\
<1 / 16 \\
<1 / 16 \\
1 / 16 \\
1 / 16\end{array}$ & $\begin{array}{r}13 \\
0 \\
2 \\
1 \\
1\end{array}$ & $\begin{array}{r}17 \\
1 \\
0 \\
2 \\
1\end{array}$ \\
\hline
\end{tabular}

gesting that when a patient with cystic fibrosis contracts a virus, mycoplasma, or coxiella infection $\stackrel{\square}{\mathbb{D}}$ significant respiratory deterioration is likely to fol- $\varrho$ low. As the deteriorated group, however, had significantly poorer lung function even before their initial visit the possibility arises that the more severely affected patients were more susceptible to such non-bacterial infections.

Infection with these organisms seems to have been directly responsible for the acute respiratory exacerbations to which they were at least temporally related. This is not surprising as it is known that some non-bacterial agents-for example, respiratory syncytial virus ${ }^{14}$ and $M$ pneumoniae, ${ }^{15}$ may cause severe lower respiratory tract infections, especially during childhood. Alternatively, the viral, myco- $\frac{}{0}$ plasma, and coxiella infections may have damaged the respiratory epithelium or other pulmonary o defence mechanisms, thereby potentiating the pathogenicity of the bacteria, particularly $P$ aeruginosa, ${ }^{8}$ already present in the lungs.

Demonstrable titres of $L$ pneumophila antibody $(\geqslant 1 / 32)$ were obtained in $17.4 \%$ of the patients with cystic fibrosis, again significantly more of these being in the deteriorated group $(p<0.05)$. This incidence compares with $22 \%$ from a study in Philadelphia," "where a group of stable patients with cystic fibrosis was screened for antibodies against $L \stackrel{\widetilde{\Phi}}{\odot}$ pneumophila as a single epidemiological observa- $\varrho$ tion. A formolised yolk sac antigen was not used in? 
Table 4 Principal bacterial pathogens in sputum of patients from the different groups at the initial visit

\begin{tabular}{|c|c|c|c|}
\hline \multirow{2}{*}{$\begin{array}{l}\text { Principal } \\
\text { bacterium }\end{array}$} & \multicolumn{3}{|c|}{ No $(\%)$ of patients } \\
\hline & $\begin{array}{l}\text { Stable group } \\
(n=22)\end{array}$ & $\begin{array}{l}\text { Deteriorated group } \\
(n=24)\end{array}$ & $\begin{array}{l}\text { Deteriorated group } \\
\text { with non-bacterial } \\
\text { infection }(n=7)\end{array}$ \\
\hline $\begin{array}{l}\text { Pseudomonas aeruginosa } \\
\text { Haemophilus infuenzae } \\
\text { Staphylococcus pyogenes }\end{array}$ & $\begin{array}{c}17(77 \cdot 3) \\
2(9 \cdot 1) \\
2(9 \cdot 1)\end{array}$ & $\begin{array}{c}20(83 \cdot 3) \\
2(8 \cdot 3) \\
1(4 \cdot 2)\end{array}$ & $\begin{array}{l}5(71 \cdot 4) \\
1(14 \cdot 3) \\
1(14 \cdot 3)\end{array}$ \\
\hline
\end{tabular}

There was no significant difference between the different groups $\left(\chi^{2}\right.$ test).

this study. Other types of antigen have produced false positive results with adenovirus ${ }^{12}$ and mycoplasma $^{16}$ infections in the past. This incidence of $17.4 \%$ with demonstrable titres of $L$ pneumophila antibody in our study contrasts signficantly with $3.4 \%$ in a population of 502 randomly selected blood donors ${ }^{17}$ and with $3.8 \%$ in a group of 1378 patients with respiratory illness not due to legionnaires' disease. ${ }^{17}$ In at least three of the eight patients with antibody titres of $1 / 32$ or more infection with $L$ pneumophila was strongly suggested. In one of these the antibody titres rose from less than $1 / 16$ to $1 / 64$ during the study and were accompanied by a respiratory illness responsive to treatment with erythromycin. We believe that this is the first time an $L$ pneumophila infection has been confirmed in a patient with cystic fibrosis. Two other patients in whom the $L$ pneumophila antibody titres showed a fourfold reduction, from $1 / 128$ one year before the present study to $<1 / 16$ at the end of the study, had both had a respiratory illness consistent with legionnaires' disease. These two patients may have been recovering from $L$ pneumophila infection between the pilot study and the present one.

Immunosuppressants, including corticosteroids, are thought to be predisposing factors in legionnaires' disease ${ }^{18}{ }^{19}$ but they did not explain the high incidence of demonstrable $L$ pneumophila antibody titres in our patients. In a study of 41 patients with asthma $20 \%$ had raised titres of antibody against $L$ pneumophila. ${ }^{10}$ There appeared to be no relationship between the presence of raised antibody titres and corticosteroid treatment.

Possibly therefore there is a higher incidence of infection with $L$ pneumophila in patients with cystic fibrosis than in healthy controls. Alternative explanations for the demonstrable $L$ pneumophila antibody titres might include overactivity of the immune system, reflected by raised immunoglobulin concentrations, ${ }^{20}$ an increased prevalence of Aspergillus fumigatus precipitins, ${ }^{21}$ or simply an anamnestic response. Serological cross reactivity between $L$ pneumophila and $P$ aeruginosa has been recorded (M Collins et al, paper presented to the 11th Euro- pean Working Group on Cystic Fibrosis, Brussels, 1982 ), which is of interest as $P$ aeruginosa was the principal bacterial pathogen in the sputum of all eight patients with $L$ pneumophila antibody titres of $1 / 32$ or more. Serological cross reactivity may not be the whole explanation, however, as the other 29 patients chronically infected with $P$ aeruginosa (table 3) did not have demonstrable titres of antibody against $L$ pneumophila. The possibility that some of the demonstrable $L$ pneumophila antibody titres detected in this study are the result of exposure to some other viral or bacterial antigen that cross reacts with $L$ pneumophila cannot be excluded.

We are uncertain why there were no patients with indirect fluorescent antibody titres of $1 / 32$ or more one year after the initial visit whereas there were eight patients in this category one month after it. Possibly the results reflect a minor epidemic of $L$ pneumophila infection, although there was no increase in the reporting of raised indirect fluorescent antibody titres in other patients in the hospital, who were suffering from a wide variety of lung disease, at the time of the initial visit. Perhaps a proportion of the patients with indirect fluorescent antibody titres of $1 / 32$ or more were showing an anamnestic reaction in the course of an acute respiratory illness. But even if this were the explanation of the raised titres, it is difficult to explain why there were more of these exacerbations at the beginning of the study than a year later, although most of the 46 patients were in fact stable one year later. We can find no reason to question the constancy of the assay method used to detect antibodies against $L$ pneumophila in this study, particularly as the same assay showed patients without cystic fibrosis to have raised indirect fluorescent antibody titres during the period of the study, and there do not appear to have been any missed cases of legionnaires' disease during this time. If patients with cystic fibrosis are indeed more susceptible to infection with $L$ pneumophila than normal people, then it is still necessary to explain whether this is due to their chronic ill health and underlying lung disease, to 
impaired immunological defences, or simply to increased exposure.

Bacteria, notably $P$ aeruginosa, are the main pathogens in patients with cystic fibrosis. Viral, mycoplasma, coxiella, and legionella infections, however, may be associated with up to a third of the acute exacerbations of respiratory disease in young adults with cystic fibrosis. These organisms, in addition to the usual bacteria, should be sought and treatment instituted where appropriate.

We would like to thank Miss M Rehahn for help with statistical analysis and Miss S Hockley for typing the manuscript.

\section{References}

' May JR, Herrick NC, Thompson D. Bacterial infection in cystic fibrosis. Arch Dis Child 1972;47:908-13.

${ }^{2}$ Hoiby N. Pseudomonas aeruginosa infection in cystic fibrosis. Diagnostic and prognostic significance of $P$ aeruginosa precipitins. Acta Path Microbiol Scand 1977;262 Sect C suppl:3-96.

${ }^{3}$ Huang NN, Van Loon EL, Sheng KT. The flora of the respiratory tract of patients with cystic flbrosis. $J$ Pediat 1961;59:512-21.

${ }^{4}$ Deforest H, Grosz H, Larayu-Cussay L, Gregory JB, Satz J, Huang HH. The association of viral and mycoplasma infections with lower respiratory tract disease in patients with cystic fibrosis. Pediatr Res 1973;6:388.

${ }^{5} \mathrm{Di}$ Sant'agnese PA. The pulmonary manifestations of fibrocystic disease of the pancreas. Dis Chest 1955;27:654-67.

${ }^{6}$ Andersen DH. Cystic fibrosis of the pancreas. J Chron Dis 1958;7:58-90.

${ }^{7}$ American Academy of Paediatrics. Report of the committee on infectious diseases. 17th ed. Philadelphia: Evanston, 1974:140.

${ }^{8}$ Petersen NT, Hoiby N, Mordhorst CH, Lind K, Flensborg EW, Brunn B. Respiratory infections in cystic fibrosis patients caused by virus, chlamydia and mycoplasma-possible synergism with Pseudomonas aeruginosa. In: Sturgess JM, ed. Perspectives in cystic fibrosis. Proceedings of the eighth international con $-\frac{\overline{\bar{S}}}{+}$ gress on cystic fibrosis. Toronto: Canadian Cystic Fib $=0$ rosis Foundation, 1980:346-51.

' Swartz MN. Clinical aspects of legionnaires' disease. Ann Intern Med 1979;90:492-5.

${ }^{10}$ Freedman AP, Katz SM. The prevalence of serum anti- $\triangle$ bodies to Legionella pneumophila in patients with chronic pulmonary disease. Am Rev Respir Dis 1981;123:238-9.

" Holsclaw DS, Katz SM. Legionnaires' disease complicating the pulmonary lesion of cystic fibrosis. In: Sturgess $\bar{\omega}$ JM, ed. Perspectives in cystic fibrosis. Proceedings of the eighth international congress on cystic fibrosis. $\vec{x}$ Toronto: Canadian Cystic Fibrosis Foundationi 1980:19a (abstract).

${ }^{12}$ Taylor AG, Harrison TG, Dighero MW, Bradstreet: CMP. False positive reactions in the indirect fluorescent antibody test for legionnaires' disease eliminated by use of formolised yolk-sac antigen. Ann Intern Med오 1979;90:686-9.

${ }^{13}$ Wright PF, Khaw KT, Oxman MN, Shwachman H.T Evaluation of the safety of amantidine-HCI and theo role of respiratory viral infections in children with cystic fibrosis. J Infect Dis 1976;134:144-9.

${ }^{14}$ Hendersen FW, Collier AM, Clyde WA, Denny FW. Respiratory syncytial virus infection, re-infections ande immunity. N Engl J Med 1979;300:530-4.

${ }^{15}$ Holt S, Ryan WF, Epstein EJ. Severe mycoplasma pneumonia. Thorax 1977;32:112-5.

${ }^{16}$ Taylor AG, Harrison TG, Andrews BE, Sillis M. Serological differentiation of legionnaires' disease and mycoplasma pneumoniae. Lancet 1980;ii: 764 .

${ }^{17}$ Harrison TG, Taylor AG. Diagnosis of Legionella pneumophila infections by means of formolised yolk sac antigens. J Clin Pathol 1982;35:211-4.

${ }^{18}$ Hernandex FJ, Kirby BD, Stanley TM, Edelstein PH.Э Legionnaires' disease in immunosuppressed patients. A PM study of 20 patients. Am J Clin Patholo 1980;73:488-95.

${ }^{19}$ Saravolatz LD, Burch KH, Fisher E, et al. The compromised host and legionnaires' disease. Ann Intern Med 1979;90:533-7.

${ }^{20}$ Hodson ME. Immunological features of cystic fibrosis. MD thesis, University of Leeds, 1977.

${ }^{21}$ Nelson LA, Callerame ML, Schwarz RH. Aspergillosis and atopy in cystic fibrosis. Am Rev Respir Dis 1979;120:863-73. 